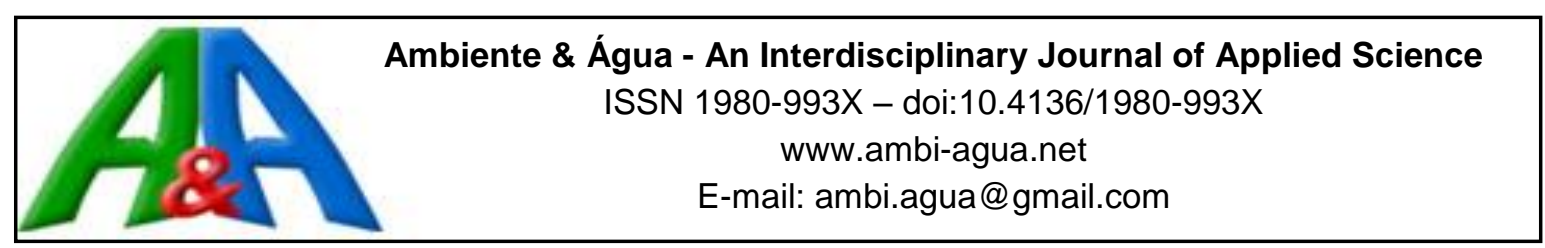

\title{
Short-term dermal exposure to tannery effluent does not cause behavioral changes in male Swiss mice
}

\author{
ARTICLES doi:10.4136/ambi-agua.2143
}

Received: 09 May 2017; Accepted: 29 Nov. 2017

\author{
Bruna de Oliveira Mendes; Abraão Tiago Batista Guimarães; Joyce Moreira de Souza; \\ Raíssa de Oliveira Ferreira; Wellington Alves Mizael da Silva; \\ Aline Sueli de Lima Rodrigues; Guilherme Malafaia* \\ Instituto Federal Goiano (IF Goiano), Urutaí, GO, Brasil \\ Programa de Pós-Graduação em Conservação de Recursos Naturais do Cerrado (PPG-CRENAC). \\ E-mail: brunamendes0107@gmail.com, abraaotbgbio@gmail.com, joycemsabio@gmail.com, \\ raissaferreira374@gmail.com, wellingtonamizael@gmail.com, alineifgoiano@gmail.com, \\ guilhermeifgoiano@gmail.com \\ *Corresponding author
}

\begin{abstract}
Tannery is a highly polluting activity due to the waste generated by bovine skin processing. Although there are several studies highlighting the health issues faced by workers exposed to tannery effluent, there are no records of experiments testing the neurobehavioral effects resulting from direct contact with this pollutant. Thus, the aim of the current study is to assess the possible neurobehavioral effects of dermal exposure to tannery effluent on male Swiss mice. Animals were divided in three groups, which were subjected to the same experimental time period and conditions: effluent group - animals in direct contact with tannery effluent (for 20 days); control group - animals in contact with pure water; and dry-control group - animals not exposed to water or to tannery effluent. Neurobehavioral tests started on the $17^{\text {th }}$ experimental day. Results of the elevated plus-maze test (anxiety prediction) showed no anxiogenic or anxiolytic effects, memory deficit or depressive symptoms on animals exposed to tannery effluent. Thus, the current results do not support the hypothesis that male Swiss mice dermal exposure to tannery effluents for the same time period and experimental conditions leads to neurobehavioral changes. Therefore, the herein adopted exposure protocol was not good to study the effects of dermal exposure to tannery effluent on the chosen experimental model.
\end{abstract}

Keywords: xenobiotic, tannery effluent, experimental model, toxicology.

\section{Curto período de exposição dérmica à efluente de curtume não provoca alterações comportamentais em camundongos Swiss machos}

\section{RESUMO}

As indústrias de curtumes são uma das atividades mais poluentes devido, sobretudo, aos resíduos produzidos durante o processamento da pele bovina. Embora estudos tenham indicado danos à saúde dos trabalhadores expostos aos efluentes de curtumes, os efeitos comportamentais resultantes do contato direto com esse poluente ainda não foram adequadamente descritos. Assim, o objetivo do presente estudo foi avaliar os possíveis efeitos comportamentais que a exposição dérmica ao efluente de curtume pode causar em machos de 
camundongos Swiss. Para isso, os animais foram distribuídos em três grupos: grupo efluente, em que os animais foram colocados em contato direto com efluente de curtume (por 20 dias); grupo controle com água, em que os animais foram colocados em contato com água, no mesmo período e condições do grupo anterior, e grupo controle seco, em que os animais não foram expostos à água ou efluente de curtume. Ao final do período experimental os animais foram submetidos ao teste do labirinto em cruz elevado (LCE), teste de reconhecimento de objeto e nado forçado. Nossos resultados não revelam efeitos ansiolíticos ou ansiogênico pelo teste do LCE, déficit de memória (pelo teste de reconhecimento de objetos) ou efeito depressivo ou antidepressivo (pelo teste do nado forçado) nos animais expostos ao efluente de curtume. Assim, conclui-se que a exposição dérmica à efluente de curtume, em curto período de tempo, não causa alterações neurocomportamentais em machos de camundongos Swiss. Logo, estudos que simulam o trabalho em condições de insalubridade de muitos trabalhadores de indústrias de curtume, que entram em contato direto com esses resíduos líquidos em períodos prolongados (crônicos), são fortemente sugeridos.

Palavras-chave: xenobiótico, efluente de curtume, modelo experimental, toxicologia.

\section{INTRODUCTION}

It is historically known that bovine skin processing has been used to supply shoe and musical instruments to remote populations for a long time (Durai and Rajasimman, 2011). However, the demand for leather-based products also grew due to population growth; this in turn led to an increase in the number of tannery industries (Durai \& Rajasimman, 2011). Nowadays, bovine skin processing has been seen as a profitable activity in many countries, mainly in developing countries such as Ethiopia, Turkey, Pakistan, Bangladesh and Brazil, where this activity ranks a relevant position in the local economy (Lofrano et al., 2013).

However, despite its economic importance, the tannery sector is known for its great polluting potential worldwide (Durai and Rajasimman, 2011). Pollution by bovine skin processing mainly results from the huge amount of chemical products used in the manufacturing process (Shakir et al., 2012; Lofrano et al., 2013), since these chemicals can be discarded into the environment through effluent and cause strong damage to the biota (Souza et al., 2016). Moreover, there is close association between the precarious work conditions in tannery plants and the their damaging effects on their workers' health, as was already reported by Costantini et al. (1989), Veyalkin and Alexander (2003), Shahzad et al. (2006), Rastogi et al. (2008) e Gowd et al. (2008), Salazar (2008), Cuberos et al. (2009). Therefore, human exposure to tannery residues is highly harmful to their health.

It is known that part of the damage to human health is caused by the precarious work conditions faced by many workers in distinct tannery facilities. Many of these companies, which are mostly located in developing countries, are small and rudimentary and do not provide minimally acceptable work conditions for people. Thus, it is quite common to find workers exposed to tannery effluent containing potentially neurotoxic organic and inorganic chemical components on a daily basis (Cuberos et al., 2009).

Murine experimental models can help in understanding the effects of contact with tannery effluent on the central nervous system, since clinical neurobehavioral research involving tannery workers is almost nonexistent. Some studies simulated tannery effluent exposure in an animal-analysis laboratory environment in order to assess the intake of water contaminated with tannery effluent (Siqueira et al., 2011; Moysés et al., 2014; Souza et al., 2016a; 2016b; Guimarães et al., 2016a; 2016b; Rabelo et al., 2016; Guimarães et al., 2017). However, these studies are incipient when it comes to the effects of dermal tannery effluent on laboratory animals. The study by Silva et al. (2016) stands out among these studies; it simulated the labor 
routine of tannery industry workers subjected to unsanitary conditions without individual protective equipment.

Thus, the aim of the current study was to analyze the effects of dermal exposure to tannery effluents on the neurobehavioral parameters of Swiss mice. Given the wide variety of inorganic and organic compounds recorded for tannery effluents, mice exposed to these pollutants were expected to suffer from the toxic effects of them, such as neurobehavioral disorders. Therefore, the present article emerges as a step forward among a series of studies focused on dermal exposure to tannery effluent.

\section{MATERIALS AND METHODS}

\subsection{Animals and experimental design}

Thirty-six (36) adult male nulliparous Swiss mice aged 1.5 months were kept in the bioterium of the Biological Research Laboratory of Goiano Federal Institute - Urutai Campus Urutaí - (Urutaí County, Goiás State, Brazil. They were kept in polypropylene boxes ( $30.3 \times 19.3 \times 12.6 \mathrm{~cm}$ - five animals in each box) under $12 \mathrm{~h}$ light/dark cycle. The boxes were stored on a ventilated shelf under controlled temperature $\left(22-25^{\circ} \mathrm{C}\right)$ and humidity Conditions $(55-60 \%)$. All the adopted procedures were approved by the Ethics Committee on Animal Use of Goiano Federal Institute, GO, Brazil (protocol N. 17/2014). Strong efforts were made in order to assure that the animals would be subjected to the least suffering possible, as well as to reduce external sources of stress, pain and discomfort. The experiment did not exceed the necessary number of animals to gather trustworthy scientific data.

Male mice were the model of choice because male workers prevail in the herein-addressed production sector (Saner et al., 1984; Veyalkin and Gerein, 2006; Khan et al., 2013; Chandrasekaran et al., 2014); therefore, men have higher risk of suffering from the effects of dermal exposure to tannery effluents.

Animals were counter-balanced according to of co-variables 'age' and 'body mass', i.e., the mean age and mean body mass of animals in the experimental groups were statistically the same. Next, the animals were divided into three experimental groups, namely: control - nonexposed to water or tannery effluent $(n=12)$; water - exposed to water $(n=12)$; and tannery effluent - exposed to tannery effluent $(n=12)$. The groups were assessed for 20 days.

Animals belonging to the tannery effluent group were kept in direct contact with the raw tannery effluent (wet blue), in transparent polycarbonate mice cages (30 x $20 \times 18 \mathrm{~cm}-7$ animals/cage, maximum) containing $150 \mathrm{~mL}$ of raw tannery effluent (wet blue) for one hour, five days a week (Monday to Friday) for 20 straight days. A perforated cage was positioned on the top of each mice cage. The herein described experimental design was adopted as an attempt to simulate the labor routine of tannery plant workers subjected to unsanitary conditions without individual protective equipment. The limbs and tail of the assessed mice had straight contact with the tannery residue layer (Figure 1A); however, the body-surface area of these animals, which was in contact with the tannery effluent, was not measured, but the paws and the tail had direct contact with the effluent. It is worth highlighting that the animals interacted with each other and ended up having almost their whole body surface wet (Figure 1B) when they were transferred to the box, so it was difficult to precisely estimate the contact surface between the animal and the pollutant.

The tannery effluent exposure protocol adopted in the current study was similar, but not identical, to the conditions humans are exposed to. Dermal exposure does not prevent oral exposure through leaching; therefore, the animals were affected by oral exposure to volatile compounds and to dermal exposure to the effluent. Similar to animals in the tannery effluent group, mice in the control group were transferred to cages containing only water as a "control substance". Body mass, as well as water or feed consumption, did not differ among the hereinanalyzed groups (data not shown). 


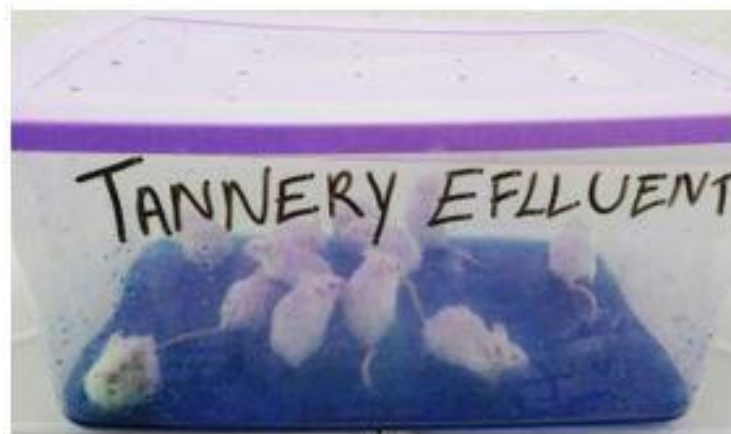

A

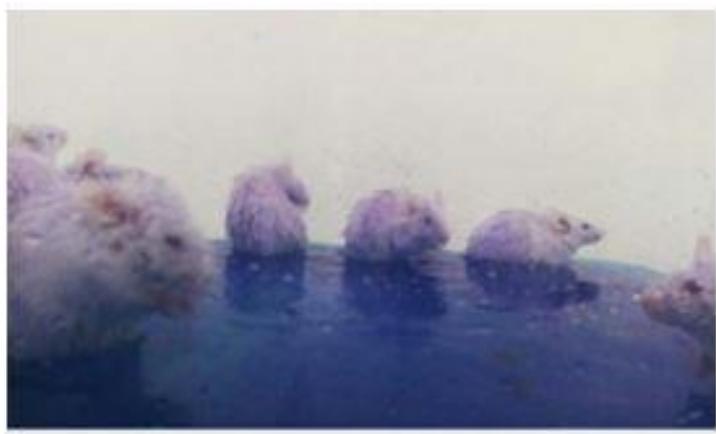

B

Figure 1. (A) Male Swiss mice exposed to tannery effluent; (B) animals appearance after few minutes exposed to the pollutant.

\subsection{Tannery effluent}

The effluent (wet-blue) used in the present study was provided by a tannery plant from Inhumas County, Goiás State, Brazil. Water and tannery effluent chemical characterizations, which were quite important to confirm the presence of heavy metals in the effluent, were performed according to the methodology recommended by the American Public Health Association (APHA, 1997) (Table 1).

Table 1. Physicochemical and chemical characterization of the tannery effluent (100\%) and water used in the present study.

\begin{tabular}{|c|c|c|c|c|}
\hline \multirow[b]{2}{*}{ Parameters } & \multirow{2}{*}{$\begin{array}{l}\text { Tannery } \\
\text { effluent } \\
(\mathbf{1 0 0 \%})\end{array}$} & \multirow[t]{2}{*}{ Water } & \multicolumn{2}{|c|}{$\begin{array}{l}\text { WHO Guidelines for drinking-water } \\
\text { Quality }{ }^{1}\end{array}$} \\
\hline & & & $\begin{array}{l}\text { Normally found in } \\
\text { freshwater/surface } \\
\text { water/groundwater }\end{array}$ & $\begin{array}{c}\text { Health-based } \\
\text { guideline by } \\
\text { WHO }\end{array}$ \\
\hline $\mathrm{pH}$ at $25^{\circ} \mathrm{C}(\mathrm{UpH})$ & 4.05 & 7.19 & No guideline & $6.5-8.5$ \\
\hline Total dissolved solids $\left(\mathrm{mg} \cdot \mathrm{L}^{-1}\right)$ & $37,380.00$ & 80.00 & No guideline & No guideline \\
\hline $\mathrm{Zn}\left(\mathrm{mg} \cdot \mathrm{L}^{-1}\right)$ & 0.30 & 0.03 & No guideline & $3.00 \mathrm{mg} . \mathrm{L}^{-1}$ \\
\hline $\mathrm{Na}\left(\mathrm{mg} . \mathrm{L}^{-1}\right)$ & $9,690.00$ & 5.01 & $<20 \mathrm{mg} . \mathrm{L}^{-1}$ & $200 \mathrm{mg} . \mathrm{L}^{-1}$ \\
\hline $\mathrm{Ca}\left(\mathrm{mg} \cdot \mathrm{L}^{-1}\right)$ & 601.20 & 4.00 & No guideline & No guideline \\
\hline $\mathrm{Mg}\left(\mathrm{mg} \cdot \mathrm{L}^{-1}\right)$ & 364.80 & 2.43 & No guideline & No guideline \\
\hline $\mathrm{Pb}\left(\mathrm{mg} \cdot \mathrm{L}^{-1}\right)$ & 0.32 & $<0.01$ & No guideline & $0.01 \mathrm{mg} . \mathrm{L}^{-1}$ \\
\hline As $\left(\mathrm{mg} \cdot \mathrm{L}^{-1}\right)$ & $<0.01$ & $<0.01$ & No guideline & $0.01 \mathrm{mg} \cdot \mathrm{L}^{-1}$ \\
\hline $\mathrm{Cr}\left(\mathrm{mg} . \mathrm{L}^{-1}\right)$ & 859.00 & $<0.05$ & $<0.002 \mathrm{mg} . \mathrm{L}^{-1}$ & $0.05 \mathrm{mg} . \mathrm{L}^{-1}$ \\
\hline $\mathrm{Cd}\left(\mathrm{mg} \cdot \mathrm{L}^{-1}\right)$ & 0.95 & $<0.001$ & $<0.002$ mg.L L $^{-1}$ & $0.003 \mathrm{mg} \cdot \mathrm{L}^{-1}$ \\
\hline $\mathrm{Ni}\left(\mathrm{mg} . \mathrm{L}^{-1}\right)$ & 5.50 & $<0.01$ & $<0.02 \mathrm{mg} . \mathrm{LL}^{-1}$ & $0.02 \mathrm{mg} . \mathrm{L}^{-1}$ \\
\hline
\end{tabular}

${ }^{1}$ The guidelines developed by the WHO for drinking-water quality was launched in Geneva in 1993 . It is the international reference for standard setting and drinking-water safety (http://www.lenntech.nl/toepassingen/drinkwater/normen/who-s-drinking-water-standards.htm.

\subsection{Neurobehavioral tests}

\subsubsection{Elevated plus maze (EPM) test}

The EPM test was performed on the $17^{\text {th }}$ experimental day and its device consisted of two opposing open arms $(30 \times 5 \times 25 \mathrm{~cm})$ and two opposing closed arms $(30 \times 5 \times 25 \mathrm{~cm})$ assembled on a central platform $(5 \times 5 \mathrm{~cm})$. The experimental apparatus was made of wood and placed $45 \mathrm{~cm}$ from the ground. The edges $(0.25 \mathrm{~cm})$ of the open arms were tested in order to prevent 
mice from falling. All the experimental groups were kept in the test room, which was soundproof, for 30 minutes under a light intensity of $100 \mathrm{~lx}$ for acclimatization purposes. Subsequently, the animals were individually placed in the center of the EPM device, with their faces turned to one of the open arms, and allowed to freely explore the apparatus for $5 \mathrm{~min}$. All the mice were tested once in the EPM device, which was cleaned with $10 \%$ ethanol before each subsequent test. The anxiety index was calculated as follows: Anxiety index $=1-$ [ [ time the animal stayed in the open arms, in seconds/test duration in seconds (300 s)] + [input frequency in the open arms/total number of entries])/2] (Guimarães et al., 2017). The total number of entries was defined by summing the number of times the animal entered the open and closed arms. A new input was accounted every time the animal had its four paws on the initial limit of the arm. In addition, the time and frequency of entries into the open arms of the EPM apparatus were assessed. The analysis applied to the behavioral parameters assessed through the EPM test was performed in the PlusMZ software.

\subsubsection{Object recognition test}

The object recognition test, which was divided into three sessions, was performed on the $18^{\text {th }}$ and $19^{\text {th }}$ experimental days in a box presenting the following dimensions: $30 \times 20 \times 13 \mathrm{~cm}^{3}$. The training session was followed by two test sessions ( $1 \mathrm{~h}$ after training and $24 \mathrm{~h}$ after training). During the training session, the animals were exposed to two familiar objects identical in size, shape and color - F1 and F2 - (squared Lego toys) for five minutes. The familiar object was replaced by a new one $(\mathrm{N})$ during the test sessions, so that animals could explore a familiar and a new object for three minutes. A triangular Lego toy was used 1 hour after the training test and a circular Lego toy was used $24 \mathrm{~h}$ after it.

The animals were placed in front of the objects at the beginning of each trial with their faces turned to the wall. The time each animal spent exploring each object was recorded. A crossed-over design was followed in all test sessions to alternate the positions of the new and familiar objects. Such procedure was adopted as a way to exclude the animals' potential preference for a certain spatial location for the objects inside the box. Exploration behavior consisted of having the animals smelling and touching the objects with their noses or forepaws, or standing $2 \mathrm{~cm}$ from the objects (or closer). The recognition index recorded for each animal was calculated according to Rabelo et al. (2016), and expressed through the ratio: $\mathrm{TOX} /(\mathrm{TF}+\mathrm{TN})$, wherein TOX $=$ time spent exploring the familiar $(\mathrm{F})$ or the new $(\mathrm{N})$ object; $\mathrm{TF}=$ time spent exploring the familiar object; $\mathrm{TN}=$ time spent exploring the new object. The boxes used in the tests were cleaned with $10 \%$ alcohol after each session.

\subsubsection{Forced swimming test}

The forced swimming test was performed on the $20^{\text {th }}$ experimental day and consisted of placing each mouse in an individual cylindrical tank (height $39.0 \mathrm{~cm}$, diameter $20.0 \mathrm{~cm}$ ) containing water at $25^{\circ} \mathrm{C}(20.0 \mathrm{~cm}$ depth $)$ for 6 minutes. Subsequently, the animals were removed from the water, dried under light heating and taken back to their boxes. All test sessions were video recorded in a camera located $30 \mathrm{~cm}$ above the tank. The recordings were used to assess the time the animals were motionless, because this variable is often used as depression predictor in the forced swimming test (Petit-Demouliere et al., 2005). Immobility was herein defined as the absence of movement in the whole body - the mouse stops fighting and keeps motionless, floating on the water, or only does the necessary movements to keep its head above the water.

\subsection{Other assessed variables}

Body mass, and the relative heart, lungs, thymus, spleen, brain, kidneys, liver, stomach and brain masses, as well as daily water and feed intake, were measured as systemic toxicity parameters. The mass of the organs was normalized to body weight through the following 
formula: organ mass (g)/body weight (g). Daily water and feed consumptions were calculated by subtracting the leftovers from the total amount of water and feed offered per day.

The locomotor activity of the animals was assessed through the Basso Mouse Scale for Locomotion (BMS), since the tests could be affected by general changes in mice's locomotion. Briefly, this method lies on evaluating biomechanical gait attributes such as leg movement and alignment, tail support, trunk stability and coordination (Basso et al., 2006). The BMS scores and subscores are calculated based on data found on the score sheet. Results of the performed evaluations were expressed by the mean score recorded for the animals in each test. It is worth noticing that the animals' locomotor activity was measured in the training and test sessions of the object recognition test.

\subsection{Data analysis}

All the statistical analyses and graph plotting were carried out in the Prism6® software (GraphPad Software, Inc., La Jolla, CA, USA). Initially, data were subjected to the AndersonDarling, Kolmogorov-Smirnov, Cramér-von Mises, Kuiper, Watson and Lilliefors normality tests, as well as to the Levene and Bartlett tests in order to check the residual variance equality. The original data did not present normal distribution and, therefore, they were transformed into $\log (\mathrm{x})$ in order to be subjected to statistical analysis. Multiple group comparisons were studied through one-way analysis of variance (ANOVA). The Tukey's multiple comparison test was performed in case of significant $F$ value $(p<0.05)$.

Data were analyzed during the training session of the control group in the object recognition test. The recognition index data recorded for each object ( $\mathrm{N}$ and $\mathrm{F})$ in the control group were measured during the test session in order to validate the object recognition test, according to Akkerman et al. (2012) and Rabelo et al. (2016); thus, the Student's t-test with Bonferroni adjustment (training session data) was also conducted. The resulting data of the new object recognition index were subjected to one-way ANOVA, and to Tukey post-hoc test at 5\% probability. The recordings from all the behavioral tests were watched by two trained observers; every single recording was analyzed twice and it led to $85 \%$ intra-observer agreement.

\section{RESULTS AND DISCUSSION}

No animal died during the experimental procedure; moreover, no sign of toxicity was observed in the animals belonging to the dry control group or in mice subjected to water or tannery effluent exposure. The physical examination applied to the mice showed no difference in animals' body mass $\left(\mathrm{F}_{(2.33)}=0.056, \mathrm{p}=0.948\right)$, daily feed $(\mathrm{g})\left(\mathrm{F}_{(2,33)}=0.094, \mathrm{P}=0.91\right)$ or water $(\mathrm{mL})$ intake per animal $\left(\mathrm{F}_{(2,33)}=0.074, \mathrm{p}=0.94\right)$ (graphs not shown). Differences in the relative mass of the assessed organs between experimental groups were not recorded: (heart $\left(\mathrm{F}_{(2,33)}=1,837, \mathrm{p}=0.189\right)$, lungs $\left(\mathrm{F}_{(2,33)}=0.797, \mathrm{p}=0.466\right)$, thymus $\left(\mathrm{F}_{(2,33)}=0.612, \mathrm{p}=0.553\right)$, brain $\left(\mathrm{F}_{(2,33)}=0.715, \mathrm{p}=0.503\right)$, kidney $\left(\mathrm{F}_{(2,33)}=0.644, \mathrm{p}=0.537\right)\left(\mathrm{F}_{(2,33)}=0.014, \mathrm{p}=0.992\right)$ and stomach $\left(\mathrm{F}_{(2,33)}=0.246, \mathrm{p}=0.784\right)$ (graphs not shown).

According to Pires Júnior et al. (2012), weight variation is one of the most commonly used parameters in toxicological assessments conducted to find the early toxic effects of a given substance on animals' organs. Therefore, different studies assessed mice body mass, as well as the relative mass of their organs in experiments focused on analyzing the effect of certain substances on these animals' bodies (Bhaskar and Mohanty, 2014; Lu al., 2014, Mukerji et al., 2015, Das et al., 2015, Olson et al., 2015). Current data suggest that treatments with emphasis on dermal exposure to effluents do not produce effects consistent with systemic toxicity in animals.

The EPM test (Figure 2A) revealed that dermal exposure to the tanning effluent does not lead to behaviors compatible with ansiogenic or anxiolytic profiles in animals, since there was 
no difference recorded for any of the assessed behavioral categories between the experimental groups (Figure 2).

Data recorded during the training session of the object recognition test (Figure 3A) showed that animals in the control group presented similar exploratory behavior (according to the Student's t-test $-p>0.05$ ) towards the familiar objects (F1 and F2), and it allowed the inference that the spatial location preferences inside the test box did not influence the animals. Moreover, animals in the control group recorded higher recognition indices for the new object than for the familiar one 24 hours after the training session. Thus, the object recognition test was validated; however, there were no statistical differences when the new object recognition indices were compared between experimental groups (Figure 3B).

There were no changes in the immobility of animals dermally exposed to the pollutant in the forced swim test (Figures 4A and 4B), which suggests that tannery effluents do not induce depression behaviors in male Swiss mice.

Finally, data in the current study evidence that the treatment did not affect the animals' locomotor activity in the EPM test $(\mathrm{F}(2,33)=0.289, \mathrm{p}=0.878)$, and in the training and test sessions of the object-recognition test $(\mathrm{F}(2,33)=0.0129, \mathrm{p}=0.978$, and $\mathrm{F}(2,33)=0.0112$, $\mathrm{p}=0.977$, respectively), as well as in the forced-swim test $\mathrm{F}(2,33)=0.333, \mathrm{p}=0.724)$. Thus, it is possible to state that the herein-tested treatments did not affect the locomotor activity of the analyzed mice (graphs not shown).

Studies have found different effects of oral exposure to tannery effluent on mammals, and their results converge to the neurotoxic potential of the assessed pollutants when it comes to predictive anxiety (Siqueira et al., 2011; Silva et al., 2016; Guimarães et al., 2016a) and anxiolytic behaviors (Almeida et al., 2016), to depression predictors (Souza et al., 2017), memory deficit (Rabelo et al., 2016), as well as to the neurobehavioral effects detrimental to the offspring of parents exposed to these xenobiotics (Guimarães et al., 2016b). The possible action of organic and inorganic effluent components on the normal functioning of the central nervous system can explain the diversity of herein observed behavioral effects. According to Souza et al. (2016a), variables such as sex, age, effluent type (derived from different bovine skin processing stages), rodent species and lines and effluent concentration, are important factors contributing to different results.

However, there are few studies on dermal exposure to tannery effluent on mice. Recently, the present research group dermally exposed male C57B16J and Swiss mice to tannery effluent and found anxiogenic behavior in C57B1/6J animals (Silva et al., 2016), differently from what was observed in the current study. On that occasion, Swiss males dermally exposed to tannery effluent for 15 days did not present changes related to anxiety disorders, even when the high neurotoxic potential of the evaluated pollutant was taken into account. Likely, the higher anxiety index observed in $\mathrm{C} 57 \mathrm{~B} 1 / 6 \mathrm{~J}$ than in Swiss mice can be related to these lines' performance in the elevated plus-maze test. According to Griebel et al. (2000), there are relevant differences in the anxiogenic behavior of mice belonging to different lines in the anxiety tests.

On the other hand, it is impossible to deny that the intrinsic biological characteristics of C57B1/6J mice may have boosted the neurotoxicity effects found in animals studied by Silva et al. (2016). Therefore, these animals may suffer from a lower or higher degree of environmental influence, and it makes these experimental models lesser or more susceptible to some xenobiotics (Casellas et al., 2010). On the one hand, the use of these experimental models only allows the experimental variables introduced by the researcher, and it significantly reduces the genetic influence of the species on the results; on the other hand, it was possible recording unobservable effects on outbred animals. 

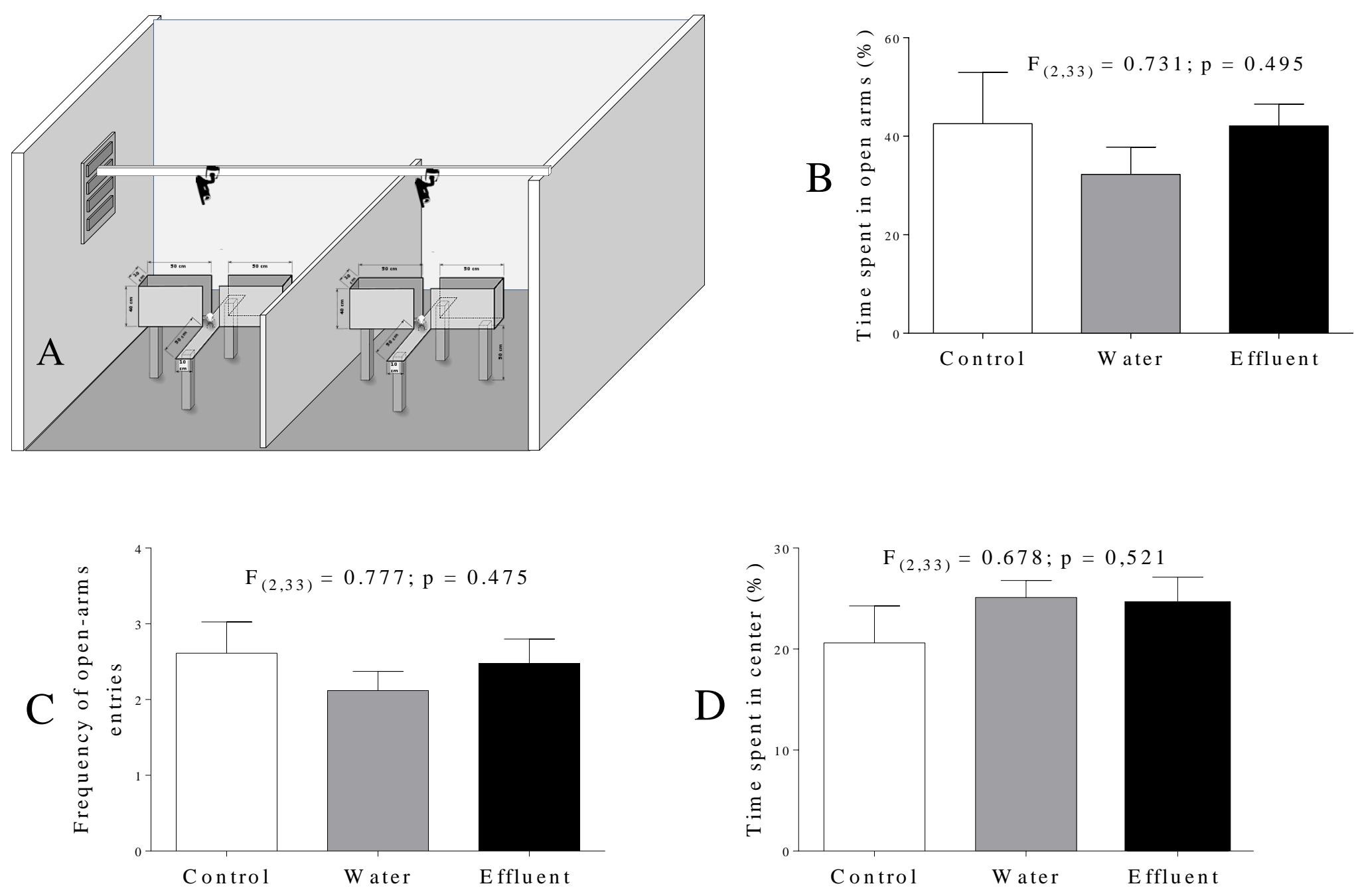

Figure 2. (A) Imaging depicting the Elevated plus maze performed in the test room (B) Time spent in the open arms; (C) frequency of entries into the open arms of the Elevated Plus-Maze and (D) anxiety index of male Swiss mice exposed or not to tannery effluent. The bars indicate the mean + SEM. Data were subjected to analysis of variance (one-way ANOVA) and Tukey post-test at 5\% probability. Control group ( $\mathrm{n}=12)$; Water group ( $\mathrm{n}=12)$ and Effluent group $(\mathrm{n}=12)$. 

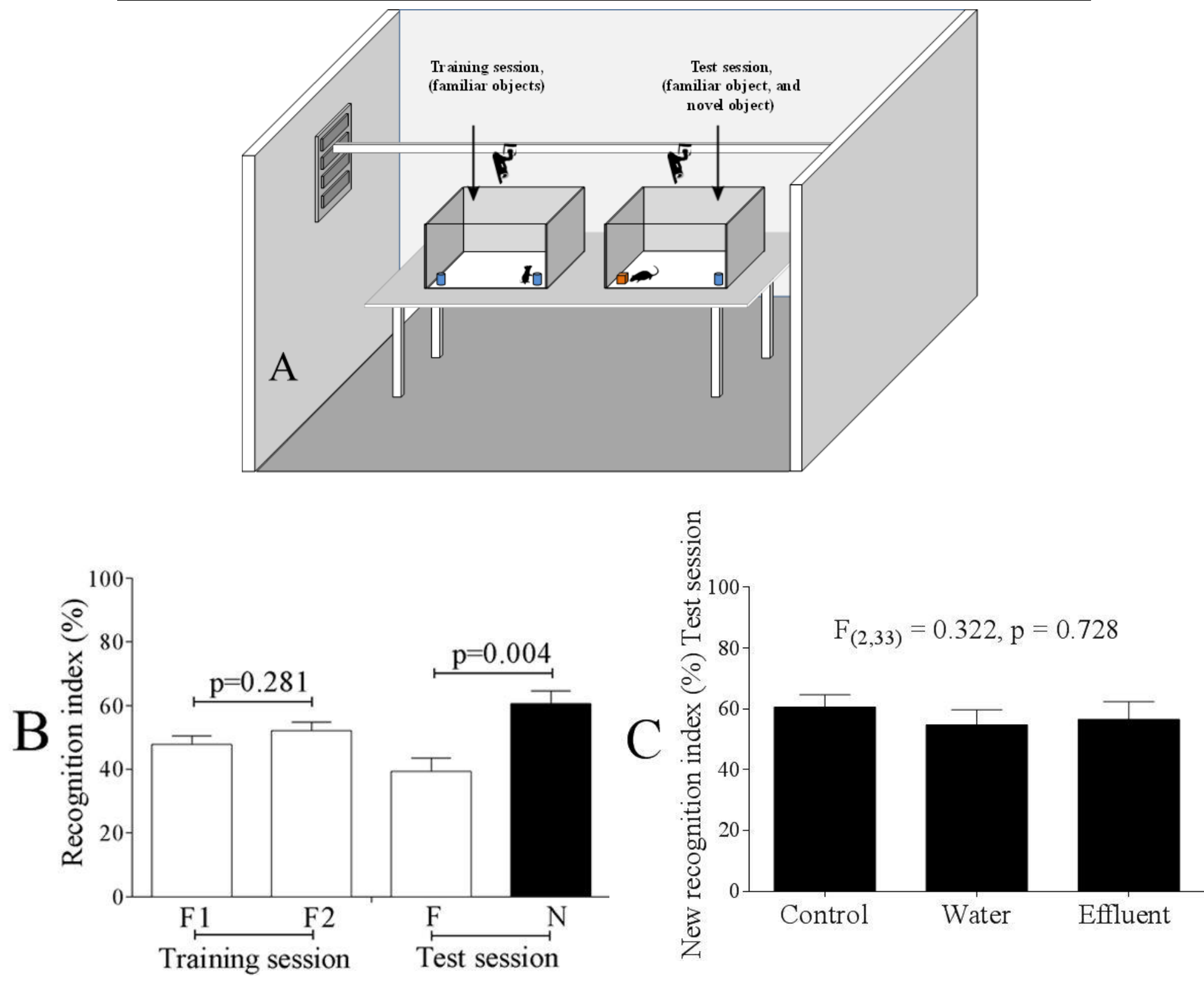

Figure 3. (A) Image depicting the object recognition test performed in the test room; (B) Object recognition indices of male Swiss mice not exposed to tannery effluent (control group), and (C) Novel object recognition indices of male Swiss mice exposed or not to tannery effluent, calculated 24 hours after the training session (test session). In "B", the Student's t-test with Bonferroni adjustment for multiple pairwise comparisons was applied, considering $\alpha=0.05$. In " $\mathrm{C}$ ", data were subjected to analysis of variance (one-way ANOVA) and Tukey post-test at 5\% probability. Control group ( $\mathrm{n}=12$ ); Water group (n=12) and Effluent group $(n=12)$. F1: familiar object 1 in the training session; F2: familiar object 2 in the training session; F: familiar object in the test session; $\mathrm{N}$ : new object in the test session. 

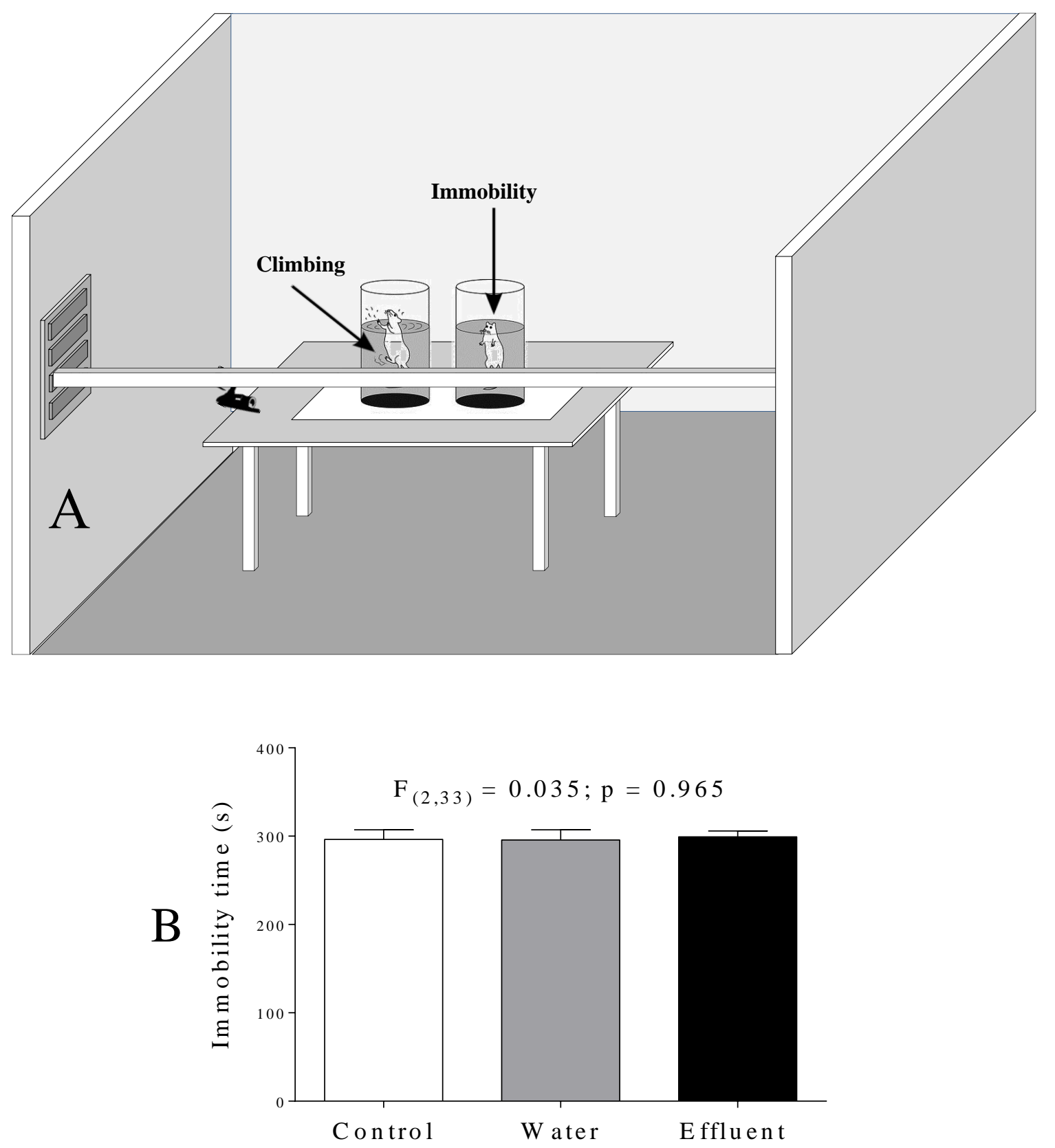

Figure 4. (A) Image depicting the forced swimming test conducted in test room; (B) Immobility in the forced swimming test of male Swiss mice exposed or not to tannery effluent. Bars indicate the mean + SEM. Data were subjected to analysis of variance (one-way ANOVA) and Tukey post-test at $5 \%$ probability. Control group $(\mathrm{n}=12)$; Water group $(\mathrm{n}=12)$ and Effluent group $(\mathrm{n}=12)$.

Outbred animals, in turn, present diversified genetic constitutions, which can exert direct influence on the susceptibility or resistance of animals to the exposure to certain pollutants. According to Campos et al. (2016), heterogenic animals are distinct from each other due to the high percentage of heterozygosity among their alleles; moreover, they are the ones who best mimic the genetic variability of typical human populations. Therefore, it is tempting to 
speculate that Swiss mice lines are more resistant to dermal exposure to tannery effluent because they require a longer exposure period to the pollutant in order to develop neurobehavioral changes.

\section{CONCLUSION}

It can be concluded that short-term dermal exposure to tannery effluent does not cause neurobehavioral changes in male Swiss mice. Thus, further studies simulating the unhealthy labor conditions faced by many workers in tannery facilities who have straight contact with these liquid residues for prolonged periods of time are recommended. These studies can be very useful to improve the knowledge about the possible impacts of this production activity on the occupational health of workers in tanning industries.

\section{ACKNOWLEDGMENT}

The authors are grateful to the Brazilian National Council for Research $(\mathrm{CNPq})$ (Brazilian research agency) (Proc. No. 467801/2014-2) and to Instituto Federal Goiano for the financial support. Moreover, the authors are grateful to the CNPq for granting scholarships to the students who conducted the current study.

\section{REFERENCES}

AKKERMAN, S. et al. Object recognition testing: methodological considerations on exploration and discrimination measures. Behavioural Brain Research, v. 232, n. 2, p. 335-347, 2012. https://doi.org/10.1016/j.bbr.2012.03.022

ALMEIDA, S. F. et al. Behavioral changes in female Swiss mice exposed to tannery effluent. Revista Ambiente \& Água, v 11, n. 3, p. 519-534, 2016. http://dx.doi.org/10.4136/ambiagua. 1852

AMERICAN PUBLIC HEALTH ASSOCIATION (APHA). Standard methods for the examination of water and wastewater. 20. ed. New York: APHA, AWWA, WPCR, 1997. $1194 \mathrm{p}$.

BASSO, D. M.; FISHER, L. C.; ANDERSON, A. J.; JAKEMAN, L. B.; MCTIGUE, D. M.; POPOVICH, P. G. Basso Mouse Scale for Locomotion Detects Differences in Recovery after Spinal Cord Injury in Five Common Mouse Strains. Journal of Neurotrauma, v. 23, n. 5, p. 635-659, 2006. https://doi.org/10.1089/neu.2006.23.635

BHASKAR, R.; MOHANTY, B. Pesticides in mixture disrupt metabolic regulation: in silico and in vivo analysis of cumulative toxicity of mancozeb and imidacloprid on body weight of mice. General and Comparative Endocrinology, v. 205, p. 2226-234, 2014. https://doi.org/10.1016/j.ygcen.2014.02.007

CAMPOS, J. D. S. et al. O comportamento do camundongo Swiss webster em biotério de experimentação: observações e reflexões. Revista da Sociedade Brasileira de Ciência em Animais de Laboratório, v. 4, n. 1, p. 32-43, 2016.

CASELLAS J. Inbred mouse strains and genetic stability: a review. Animal, v. 5, n. 1, p. 1-7, 2010. https://doi.org/10.1017/S1751731110001667

CHANDRASEKARAN, V.; DILARA, K.; PADMAVATHI, R. Pulmonary functions in tannery workers - A cross sectional study. Indian Journal of Physiology and Pharmacology, v. 58, n. 3, p. 206-210, 2014. 
COSTANTINI, A. S. et al. Cancer mortality among workers in the Tuscan tanning industry. British Journal of Industrial Medicine, v. 46, n. 6, p. 384-388, 1989.

CUBEROS, E.; RODRIGUEZ A. I.; PIETRO, E. Niveles de cromo y alteraciones de saluden una poblaciónexpuesta a lasactividades de curtiembresen Bogotá, Colombia. Revista Salud Pública, v. 11, n. 2, p. 278-289, 2009.

DAS, K. P. et al. Developmental toxicity of perfluorononanoic acid in mice. Reproductive Toxicology, v. 51, p. 133-144, 2015. https://doi.org/10.1016/j.reprotox.2014.12.012

DURAI, G.; RAJASIMMAN, M. Biological Treatment of Tannery Wastewater - A Review. Journal of Environmental Science and Technology, v. 4, n. X, p. 1-17, 2011. https://doi:10.3923/jest.2011.1.17

GOWD, S. S.; GOVIL, P. K. Distribution of heavy metals in surface water of Ranipet industrial area in Tamil Nadu, India. Environmental Monitoring and Assessment, v. 136, n. 1-3, p. 197-207, 2008. https://doi:10.1007/s10661-007-9675-5

GRIEBEL, G.; BELZUNG, C.; PERRAULT, G.; SANGER, D. J. Differences in anxietyrelated behaviours and in sensitivity to diazepam in inbred and outbred strains of mice. Psychopharmacology, v. 148, n. 2, p. 164-170, 2000. http://doi:10.1007/s002130050038

GUIMARÃES, A. T.; FERREIRA, R. O.; RODRIGUES, A. S. L.; MALAFAIA, G. Memory and depressive effect on male and female Swiss mice exposed to tannery effluent. Neurotoxicology and Teratology, v. S0892-0362, n. 16, p. 30160-X, 2017. https://doi.org/10.1016/j.ntt.2017.03.003

GUIMARÃES, A. T. B. et al. The C57BL/6J mice offspring originated from a parental generation exposed to tannery effluents shows object recognition deficits. Chemosphere, v. 164, p. 593-602, 2016a. https://doi.org/10.1016/j.chemosphere.2016.08.144

GUIMARÃES, A. T. B. et al. Anxiety and memory deficits induced by tannery effluent in C57BL/6J female mice. Environmental Science and Pollution Research, v. 23, n. 24, p. 25323-25334, 2016b. https://doi:10.1007/s11356-016-7746-2

KHAN, D. A.; MUSHTAQ, S.; KHAN, F. A.; KHAN, M. Q. Toxic effects of chromium on tannery workers at Sialkot (Pakistan). Toxicology and Industrial Health, v. 29, n. 2, p. 209-215, 2013. https://doi:10.1177/0748233711430974

LOFRANO, G.; MERIÇ, S.; ZENGIN, G. E.; ORHON, D. Chemical and biological treatment technologies for leather tannery chemicals and wastewaters: a review. Science of the $\begin{array}{llllll}\text { Total Environment, } & \text { v. 461-462, p. 265-281, }\end{array}$ https://doi.org/10.1016/j.scitotenv.2013.05.004

LU, L. et al. Safety assessment of the fermented Phylloporia ribis (Lonicera japonica Thunb.) mycelia by oral acute toxicity study in mice and 90-day feeding study in rats. Food and Chemical Toxicology, v. 69, p. 18-24, 2014. https://doi.org/10.1016/j.fct.2014.03.044

MOYSÉS, F. S. et al. Exposition to tannery wastewater did not alter behavioral and biochemical parameters in Wistar rats. Physiology and Behavior, v. 129, p. 160-166, 2014. https://doi.org/10.1016/j.physbeh.2014.02.022

MUKERJI, P.; ERA, J. C.; BUCK, R. C.; O’CONNOR, J. C. Oral repeated-dose systemic and reproductive toxicity of 6:2 fluorotelomer alcohol in mice. Toxicology Reports, v. 2, p. 130-143, 2015. https://doi.org/10.1016/j.tox.2014.01.002 
OLSON, J. A. et al. Toxicity and efficacy differences between liposomal amphotericin B formulations in uninfected and Aspergillus fumigatus infected mice. Medical Mycology, v. 53, n. 2, p. 107-118, 2015. https://doi:10.1093/mmy/myu070

PETIT-DEMOUlIERE, B.; CHENU, F.; BOURIN, M. Forced swimmnig test in mice; a review of antidepressant activity. Phychophamacology, v. 177, n. X, p. 245-255, 2005. https://doi:10.1007/s00213-004-2048-7

PIRES JÚNIOR, H. B. et al. Avaliação da toxicidade aguda do extrato hexânico de frutos de Melia azedarach (Meliaceae) em camundongos. Ciência Animal Brasileira, v. 13, n. 4, p. 512-519, 2012. https://doi:10.5216/cab.v13i4.15179

RABELO, L. M. et al., Memory deficit in Swiss mice exposed to tannery effluent.

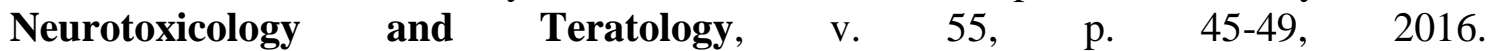
https://doi.org/10.1016/j.ntt.2016.03.007

RASTOGI, S. K.; AMIT, P.; SACHIN, T. Occupational health risks among the workers employed in leather tanneries at Kanpur. Indian Journal of Occupational and Environmental Medicine, v. 12, n. 3, p. 132-135, 2008. https://doi:10.4103/00195278.44695

SALAZAR, E. M. G. Economía ecológica frente a economía industrial. El caso de la indústria de lac curtiduría em México. Argumentos, v. 21, n. 56, p. 55-71, 2008.

SANER, G.; YÜZBAȘIYAN, V.; ÇIGDEM, S. Hair chromium concentration and chromium excretion in tannery workers. British Journal of Industrial Medicine, v. 41, n. 2, p. 263 266, 1984.

SHAHZARD, K.; AKHTAR, S.; MAHMUD, S. Prevalence and determinants of asthma in adult male leather tannery workers in Karachi, Pakistan: a cross sectional study. BMC Public Health, v. 6, p. 292-298, 2006. https://doi:10.1186/1471-2458-6-292

SHAKIR, L. et al. Ecotoxicological risks associated with tannery effluent wastewater. Environmental Toxicology and Pharmacology, v. 34, p. 180-191, 2012. https://doi.org/10.1016/j.etap.2012.03.002

SIQUEIRA, I. R.; VANZELLA, C.; BIANCHETTI, P.; RODRIGUES, M. A.; STÜLP, S. Anxiety-like behaviour in mice exposed to tannery wastewater: the effect of photoelectrooxidation treatment. Neurotoxicology and Teratology, v. 33, n. 4, p. 481484, 2011. https://doi.org/10.1016/j.ntt.2011.05.008

SILVA, W. A. et al. Dermal exposure to tannery effluent causes neurobehavioral changes in C57B1/6J and Swiss mice. Chemosphere, v. 160, p. 237-243, 2016. https://doi.org/10.1016/j.chemosphere.2016.06.083

SOUZA, J. M. et al. Histopathological assessment of C57B1/J mice organs exposed to tannery effluents. Revista Ambiente \& Água, v. 11, n. 1, p. 24-34, 2016 a. http://dx.doi.org/10.4136/ambi-agua.1694

SOUZA, J. M. et al. Inbred mice strain shows neurobehavioral changes when exposed to tannery effluent. Environmental Science and Pollution Research, v. 24, n. 2, p. 20352046, 2017. https://doi:10.1007/s11356-016-7949-6 
SOUZA, J. M.; GUIMARÃES, A. T. B.; SILVA, W. A. M.; PEREIRA, C. C. O.; MENEZES, I. P. P.; MALAFAIA, G. Tannery effluent effects in vertebrates: lessons from experimental animals. International Journal of Current Research, v. 8, n. 10, p. 39902-39914, 2016b.

VEYALKIN, I.; GEREIN, V. Retrospective cohort study of cancer mortality at the minsk leather tannery. Industrial Health, v. 44, n. 1, p. 69-74, 2006. http://doi.org/10.2486/indhealth.44.69

VEYALKIN, I. V.; ALEXANDER, A. M. Proportionate cancer mortality among workers in the Belarussian tanning industry. American Journal of Industrial Medicine, v. 44, n. 6 , p. 637-642, 2003. http://doi:10.1002/ajim.10275 